\title{
Liver Transplantation for Non A-E Related Acute Liver Failure in Children
}

\section{Non A-E llișkili Akut Karaciğer Yetmezliği Olan Çocuklarda Karaciğer Nakli}

\author{
Maşallah Baran1, Gökhan Tümgör1, Murat Çakır1, Çiğdem Arıkan2, Murat Kılıç2, \\ Sema Aydoğdu1 \\ ${ }^{1}$ Ege University Faculty of Medicine, Department of Pediatric Gastroenterology, Hepatology and Nutrition, Izmir, Turkey \\ 2Kent Hospital, Organ Transplantation Center, Department of Pediatric Gastroenterology, Hepatology and Nutrition, Izmir, Turkey
}

\begin{abstract}
Aim: Non A-E hepatitis constitutes the significant portion of acute viral hepatitis with undefined etiology. It is characterized by its propensity to cause severe hepatitis with high fatality rate without liver transplantation (LT). We aimed to evaluate demographic, clinical features and outcome of children who underwent LT due to Non A-E related acute liver failure (ALF). Materials and Methods: One hundred sixty-two liver transplants were performed on 152 children $(79 \mathrm{M}, 73 \mathrm{~F})$ in our transplantation center during the study period. Six patients were considered Non A-E hepatitis related ALF. Demographic, clinical and laboratory findings and outcome of 6 children were analyzed from the hospital file records.

Results: Five patients had grade III and one patient grade II encephalopathy. Histopathological examination of the explanted liver revealed submassive or massive hepatic necrosis in all patients. Three patients $(50 \%)$ had regenerative nodules. After $\mathrm{LT}$, three cases $(50 \%)$ had temporary neurological problems, and all of them improved within 3 weeks. One patient (16.6\%) developed aplastic anemia that was unresponsive to supportive treatment and culminated in the loss of the patient. The other patient was lost due to septicemia. None of the survival patients had relapse of hepatitis after LT. Conclusion: LT for Non A-E hepatitis related ALF has increased morbidity in children; and apart from temporary neurological complications, aplastic anemia is a major problem in these patients. The Journal of Pediatric Research 2014;1(1):28-32
\end{abstract}

Key Words: Liver transplantation, non A-E hepatitis, children

\section{ÖZET}

Amaç: Nedeni saptanamayan viral hepatitlerin önemli bir kısmını non A-E hepatitler oluşturmaktadır.Hastaların önemli bir kısmında bulgular ağır seyretmektedir ve karaciğer nakli yapılmazsa mortalite yüksektir. Yazımızda non A-E fulminan karaciğer hastalı̆ı nedeniyle karaciğer nakli yapılan çocuklarda demografik, klinik özellikler ve sonuçlarının değerlendirilmesi amaçlanmıştır.

Gereç ve Yöntem: Çalışma süresi içinde organ nakil merkezimizde 152 çocuk hastaya (79 E, $73 \mathrm{~K}$ ) 162 karaciğer nakli yapılmıştır. Bu hastalardan 6 hasta non A-E fulminan hepatit tanısı almıştır. Altı hastanın dosya ve hastane kayıtları incelendi, olguların demografik, klinik ve laboratuvar bulguları ve nakil sonuçları değerlendirildi.

Bulgular: Beş hastada evre III, bir hastada evre 2 ensefalopati saptandı. Tüm hastaların alınan karaciğer histopatolojisinde masif ve submasif nekroz ile uyumlu bulgular gözlendi. Üç hastada rejeneratif nodül formasyonu saptandı. Üç hastada (\%50) karaciğer nakli sonrası nörolojik problemler saptandı, nörolojik bulguların 3 hafta içinde gerilediği gözlendi. Bir $(\% 16,6)$ hastada aplastik anemi saptandı, destek tedavisine rağmen hasta kaybedildi. Bir hasta septisemiden kaybedildi. Yaşayan 4 olguda relaps hepatit gözlenmedi.

Sonuç: Non A-E fulminan hepatitlerde karaciğer nakli sonrası morbidite riski artmıştır. Bu hastalarda geçici nörolojik problemler ve aplastik anemi önemli sorun oluşturmaktadır. The Journal of Pediatric Research 2014;1(1):28-32

Anahtar Kelimeler: Karaciğer nakli, non A-E hepatit, çocuk 


\section{Introduction}

Acute liver failure (ALF) is a clinical syndrome characterized by a sudden onset impaired liver function, progressive jaundice and encephalopathy without symptoms of previous liver disease $(1,2)$. Currently, there are no specific therapies of proven benefit except for emergency liver transplantation. Etiology of liver failure depends on age in pediatric population and it is reported to vary with geographical location (3). However, viral agents tend to be the leading cause worldwide (4).

Non-A-E hepatitis probably originates from stil unidentified viruses (5). There isn't much information on the frequency of Non A-E hepatitis that varies between 2.9\%$15 \%$ by geographical location in childhood (6-8). The degree of abnormality in aminotransferases activities is milder compared to other etiologies and chronicity may be noted in $12 \%$ of the cases. Fulminant hepatitis occurred in 1.8\%-12\% of the patients (9). Young age carried a significantly higher risk of having a fulminant course (10).

There are many causes of $\mathrm{FH}$ which vary with geographic region. The most frequent causes worldwide include viral hepatitis (particularly hepatitis $A(H A V)$ and $B(H B V)$ ), medication overdose (in particular paracetamol), idiosyncratic drug reactions, ingestion of toxins and metabolic disorders. Prevalence of Non A-E hepatitis was found approximately $14 \%-30 \%$ in patients with ALF (11). In pediatric cohort; the prevalence varies between $5 \%$ to $30 \%$ (6). Fulminant Non A-E is characterized by its propensity to cause severe hepatitis with high fatality rate (approximately 50\%) (low spontaneous remission) without liver transplantation and is associated with bone marrow failure in up to $10 \%$ of patients. Additionally; compared with fulminant hepatitis B, fulminant Non A-E hepatitis had a trend of a longer interval from onset to death (10).

We aimed to analyze the demographic and clinical features and outcome of children who underwent liver transplantation due to Non A-E related ALF.

\section{Materials and Methods}

Between September 1997 to February 2009, 162 liver transplants were performed on 152 children (79 M, 73 F) at Ege University, Organ Transplantation and Research Center. Twenty-five liver transplants were performed on 24 children ( $\leq 17$ years old) with ALF. The etiologies of ALF in children were; Hepatitis A in 12 patients, amanita phalloides in 3 patients, toxic hepatitis in 2 patients and Wilson's disease in 1 patients. Six patients (3.7\% of all liver transplanted children, $25 \%$ of children with ALF) were considered Non A-E hepatitis related ALF. Demographic, clinical and laboratory findings and outcome of 6 children with Non A-E hepatitis related ALF were analyzed from the hospital file records.

All the children with suspected ALF, who were previously healthy, underwent detailed laboratory examination for the etiologic agent including autoimmune markers (immunoglobulin levels, liver autoantibodies), Wilson disease (24-hour urinary copper excretion, ceruloplasmin, KayserFleischer rings and dry copper level of explanted liver), hemophagocytic lymphohistiocytosis (clinical, laboratory and bone marrow if necessary), $\alpha 1$-antitrypsin level and genotype and metabolic diseases (urinary succinylacetone and other metabolites). Viral serological evaluation includes hepatitis A, B, C, D and E serological markers and HBV DNA PCR, HCV RNA PCR, CMV antigen and CMV DNA PCR, EBV VCA IgM, PCR for EBV and Parvovirus B19 DNA, HIV analyses in all cases. IFAT and ELISA tests for toxoplasmosis IgM and IgG, VZV, HSV were also evaluated in suspected patients. The diagnosis of acute Non A-E hepatitis was made by the exclusion of major hepatitis viruses and also of other causes of ALF.

ALF was classified as hyperacute, acute and subacute if the time interval between the onsets of jaundice to encephalopathy was less than 7 days, between 8-28 days and more than 28 days, respectively (4).

After transplantation with a compatible donor, patients were followed in the intensive care unit in the first week, then in the transplantation clinic. Thereafter, patients were followed in outpatient transplantation clinic with intervals. Baseline immunosuppression varied over time according to ongoing protocols, corticosteroid, cyclosporine or tacrolimus was started on all patients as the main immunosuppressive treatment after liver transplantation.

\section{Results}

Liver transplantation was performed on 6 patients (3 M, 3 F, median age 7.5 and range 4-14 years old) due to Non A-E hepatitis related ALF. All the patients had prodromal periods such as subfebrile fever $\left(37-38{ }^{\circ} \mathrm{C}\right)$, malaise, fatigue and vomiting suggesting a viral disease. Onset of encephalopathy was acute in 2 patients and subacute in the others. Five patients had grade III, and one patient grade II encephalopathy. At admission; anemia $(n=6)$ and leukopenia $(n=1)$, thrombocytopenia $(n=2)$ were seen in the patients. Clinical and laboratory findings are shown in Table I and Table II .

Five patients had living donors (parents in all of them) and the donor of 1 patient was cadaveric. The median time period between admission and transplantation was 13 days (3-32 days). Histopathological examination of the explanted liver revealed submassive or massive hepatic necrosis in all patients. In addition; especially plasma cell infiltration to portal area were seen in all patients. Three patients had regenerative nodules. These three patients had long illness duration (median days; 22 vs. 8 days) and had liver transplantation later (median days; 15 vs. 3 days) than the others. Immunohistochemical examination for $\mathrm{HBsAg}$ and $\mathrm{HBcAg}$ and histochemical staining for reticulum, copper, orcein, iron and d-PAS were negative in all patients.

Two of the patients with grade III encephalopathy had temporary tremor after the transplantation, which disappeared within 3 weeks, and one patient with grade III 
encephalopathy had temporary blindness which improved within 3 weeks. Immunosuppression levels, electrolytes, magnesium levels and blood pressure were normal in all patients with neurological complications. On long term none of the patients had any neurological and cognitive complications.

Four patients received tacrolimus and the other cyclosporine after the transplantation. One patient had acute rejection following transplantation and improved within one week with increased immunosuppression.

Case 1, whose live donor was her mother and had normal hemogram levels before the transplantation, developed pancytopenia on the $3^{\text {rd }}$ day of transplantation. Absolute neutrophil count decreased to $100 / \mathrm{mm}^{3}$, hemoglobin 7.6 $\mathrm{gr} / \mathrm{dl}$, platelets $25.000 / \mathrm{mm}^{3}$ and reticulocyte $0.5 \%$ on the 12th day of transplantation. Bone marrow aspiration showed decreased cellularity. The patient died in intensive care unit because of uncontrollable sepsis and septic shock despite intense antibiotherapy with granulocyte infusions and supportive treatment on post-operative 54th day; Case 3 also died due to sepsis on post- operative $7^{\text {th }}$ day, hematologic findings showed that pancytopenia (White blood cell count decreased to $820 / \mathrm{mm}^{3}$, hemoglobin $9 \mathrm{gr} / \mathrm{dl}$, platelets 20.000/ mm3, MCV $86 \mathrm{fl}$ ) on postoperative 5th day (Table III). The other four patients are being followed up in outpatient transplantation clinic and are in good clinical condition.

Mortality was seen after liver transplantation of acute liver failure due to hepatitis A 2/12 (17\%), of toxic liver failure (none) and of non A-E 2/6 (33\%).

\section{Discussion}

In this manuscript; we report our experience about demographic and clinical findings, and outcome of liver transplantation in children with Non A-E related ALF. It constitutes $3.7 \%$ of all liver transplanted children and $25 \%$ of the children that underwent transplantation due to ALF. After liver transplantation, three cases had temporary

\begin{tabular}{|c|c|c|c|c|c|c|}
\hline & Case 1 & Case 2 & Case 3 & Case 4 & Case 5 & Case 6 \\
\hline Age (years) & 10 & 14 & 10 & 5 & 5 & 4 \\
\hline Gender & $F$ & $M$ & $\mathrm{~F}$ & $M$ & $\mathrm{~F}$ & $M$ \\
\hline Onset of encephalopathy & Acute & Subacute & Subacute & Subacute & Acute & Subacute \\
\hline Encephalopathy grade & III & II & III & III & III & III \\
\hline Jaundice to encephalopathy, days & 7 & 24 & 15 & 28 & 8 & 22 \\
\hline PELD score & 28 & 26 & 34 & 42 & 43 & 30 \\
\hline Postoperative outcome & Aplastic anemia ex & Live & $\begin{array}{l}\text { Sepsis, } \\
\text { Pancytopenia, ex }\end{array}$ & $\begin{array}{l}\text { Temporary Tremor, } \\
\text { Live }\end{array}$ & \begin{tabular}{|l|} 
Temporary \\
blindness Live
\end{tabular} & \begin{tabular}{|l} 
Temporary \\
tremor Live
\end{tabular} \\
\hline
\end{tabular}

PELD score: Pediatric end-stage liver disease score

Table II. Laboratory findings of the patients at initial admission

\begin{tabular}{|c|c|c|c|c|c|c|}
\hline & Case 1 & Case 2 & Case 3 & Case 4 & Case 5 & Case 6 \\
\hline Hemoglobin (g/dl) & 10.8 & 8 & 7.6 & 11 & 10 & 7.4 \\
\hline RDW & $29(11-14)$ & $26(11-14)$ & $21(11-14)$ & $17(11-14)$ & $22(11-14)$ & $34(11-14)$ \\
\hline MCV (fl) & $70(80-96)$ & $76(80-96)$ & $89(80-96)$ & $86(80-96)$ & $79(80-96)$ & $58(80-96)$ \\
\hline WBC (/mm3) & 7800 & 4100 & 5600 & 2880 & 7200 & 4746 \\
\hline ANC & 4100 & 1000 & 2000 & 500 & 5000 & 900 \\
\hline Plt & 251000 & 156000 & 26000 & 48000 & 345000 & 478000 \\
\hline ALT (IU) & 520 & 517 & 106 & 27 & 456 & 123 \\
\hline AST (IU) & 385 & 527 & 203 & 35 & 232 & 149 \\
\hline INR & 2.1 & 2 & 2.6 & 3.5 & 3.6 & 2.7 \\
\hline Total/direct bilirubin (mg/dl) & $37 / 27$ & $23 / 9$ & $39 / 22$ & $19 / 5$ & $27 / 14$ & $27 / 15$ \\
\hline Albumin (g/dl) & 4.3 & 3.1 & 5 & 3.9 & 3.4 & 4.9 \\
\hline
\end{tabular}

ANC: absolute neutrophils count, WBC: white blood cell count, Plt: Platelet count, MCV: Mean corpusculary volume of erytrocyte RDW: red blood cell distribution width, INR: International normalised ratio 
Baran et al.

Liver Transplantation in Non A-E Hepatitis

Table III. Transplantation parameters, explant liver histology and outcome of the patients

\begin{tabular}{|l|l|l|l|l|l|l|}
\hline & Case 1 & Case 2 & Case 3 & Case 4 & Case 5 & Case 6 \\
\hline Donor type & Mother & Mother & Cadaveric & Father & Mother & Father \\
\hline Time of transplantation, days & 3 & 15 & 32 & 3 & 3 & 12 \\
\hline Explant histology & Submassive HN* & $\begin{array}{l}\text { Submassive HN, } \\
3 \text { RN\$ \& MS }\end{array}$ & Submassive HN, 1 RN & Massive HN & Massive HN & $\begin{array}{l}\text { Submassive } \\
\text { HN, 1 RN }\end{array}$ \\
\hline Type of immunosupression & Tacrolimus & Cyclosporine & NPø & Tacrolimus, MMF0 & Tacrolimus & Tacrolimus \\
\hline Postoperative complications & Pancytopenia & Urticaria & Sepsis & $\begin{array}{l}\text { Temporary tremor, } \\
\text { acute rejection }\end{array}$ & $\begin{array}{l}\text { Temporary } \\
\text { blindness }\end{array}$ & $\begin{array}{l}\text { Temporary } \\
\text { tremor }\end{array}$ \\
\hline Follow-up duration & 54 days & 12 years & 3 days & 21 months & 7 years & 15 months \\
\hline Outcome & Exitus & Alive & Exitus & Alive & Alive & Alive \\
\hline
\end{tabular}

${ }^{*} \mathrm{HN}$ : hepatic necrosis, \$RN: regenerative nodules, $\beta M S$ : macrovesicular steatosis, ØNP: not prescribed and ${ }^{0 M M F: ~ m y c o p h e n o l a t e ~ m o f e t i l ~}$

neurological problems, and all of them improved within the $3^{\text {rd }}$ week. One patient developed aplastic anemia that was unresponsive to supportive treatment and culminated in the loss of the patient. The other patient who had pancytopenia was lost due to septicemia in the early postoperative period and bone marrow aspiration wasn't possible due to sepsis. The outcome of the patients were poor compared to patients with other etiologies of ALF in our center. None of the survival patients had relapse of hepatitis after liver transplantation.

Aplastic anemia is are after liver transplantation. Its incidence has been estimated to be $0.007 \%$ (9). It is observed in $23.2 \%-33 \%$ of patients who underwent liver transplantation for ALF due to Non A-E viral hepatitis $(12,13)$. Studies suggest that aplastic anemia is a complication of Non A-E viral hepatitis, rather than due to the process of transplantation, as aplastic anemia does not generally occur following liver transplantation for other reasons (14). Its occurrence is more frequent in children than in adults $133 \%$ vs. $5 \%)$, and is generally seen within the first month after transplantation. The main mechanism for the aplastic anemia is viral agent induced immune dysregulation due to activated CD8+ cells. Myelosuppresive drugs such as azathioprine and trimethoprim used after liver transplantation and environmental factors also account for the aplastic anemia. Full hematologic recovery following immunosuppression has been reported, however time of recovery is often in the order of several months to years. Despite bone marrow transplantation and intensive care, mortality rate is still very high- greater than 50\%. Systemic infections and bleeding were the most frequent causes of death, occurring in $67 \%$ and $25 \%$ of the patients, respectively (13). Incidence of neurological complications after liver transplantation ranges from $8 \%-45 \%$ (15). Seizures and tremor were the most common neurological complications, and commonly seen in the first month following liver transplantation. Causes of seizuresare multifactorialand include metabolic derangements, treatment with immunosuppressive agents, hypoxic ischemic injury, cerebral structural lesions and infections. ALF, Wilson's diseases and autoimmune hepatitis have increased risk of postoperative neurological complications. Tremor is a minor complaint compared to seizures, the prevalence varies between $2 \%-16 \%$ and is generally related with mild neurotoxic effect of immunosuppressive agents $(14,16)$. High percentage $(50 \%)$ of neurological complications of our patient group is mainly related with the ALF, three had grade III encephalopathy prior to transplantation. It was seen that the duration and the stage of pretransplant coma strongly correlated with the incidence of neurological complications. Large numbers of patients need to be examined for the effect of Non A-E hepatitis against the risk of postoperative neurological complications.

An interesting finding of our study is that half of the patients had regenerative nodules in the histopathological examination of the explanted liver. Poff et al. (17) reported that $43 \%$ of adult patients with ALF had hepatic surface nodularity at pre-transplantation imaging and $85 \%$ of these patients had alternating foci of confluent regenerative nodules and necrosis in the histopathological examination of the explanted liver. Regenerative nodules are common in adult patients with ALF who had longer illness duration and mildly elevated liver enzymes (17). Hepatic necrosis is the major histopathological feature of ALF and the severity of hepatic necrosis depends on the length of time elapsed between the insult and time at histologic examination, the etiology of the hepatic necrosis, and whether the injury is solitary, repeated, or continuous (18). In less severe forms of hepatic necrosis, there may be residual patches of hepatic parenchyma, which have been not affected by the noxious process. With recovery, scattered hepatocyte islands appear in the collapsed areas and form regenerative nodules which lack a true lobular architecture. Regenerative nodules may be related with longer illness duration in our patients.

Although it is difficult to draw a conclusion with the limited number of cases; liver transplantation for Non A-E hepatitis related ALF have increased postoperative morbidity in children; and have poor prognosis compared to other etiologies. Apart from temporary neurological complications, aplastic anemia is a major problem in these patients. 


\section{References}

1. Lu BR, Gralla J, Liu E, Dobyns EL, Narkewicz MR, Sokol RJ. Evaluation of a scoring system for assessing prognosis in pediatric acute liver failure. Clin Gastroenterol Hepatol 2008; 6: $1140-5$.

2. Narkewicz MR, Dell Olio D, Karpen SJ, et al. Pattern of diagnostic evaluation for the causes of pediatric acute liver failure: an opportunity for quality improvement. J Pediatr 2009; 155: 801-6.

3. Dhawan A. Etiology and prognosis of acute liver failure in children. Liver Transpl 2008; 14 Suppl 2: 80-4.

4. Squires Rh JR. Acute liver failure in children. Semin Liver Dis 2008; 28: 153-66.

5. Paraná R, Codes L, Andrade Z, et al. Clinical, histologic and serologic evaluation of patients with acute non-A-E hepatitis in north-eastern Brazil: is it an infectious disease? Int $\mathrm{J}$ Infect Dis 2003; 7: 222-30.

6. Aydoğdu S1, Ozgenç F, Yurtsever S, Akman SA, Tokat Y, Yağci RV. Our experience with fulminant hepatic failure in Turkish children: etiology and outcome. J Trop Pediatr 2003; 49: 36770.

7. Jaiswal SB1, Chitnis DS, Asolkar MV, Naik G, Artwani KK. Aetiology and prognostic factors in hepatic failure in central India. Trop Gastroenterol 1996; 17: 217-20.

8. Moreira-Silva SF1, Frauches DO, Almeida AL, Mendonça $\mathrm{HF}$, Pereira FE. Acute liver failure in children: observations in Vitória, Espírito Santo State, Brazil. Rev Soc Bras Med Trop 2002; 35: 483-6.
9. Tassopoulos NC, Papatheodoridis GV, Delladetsima I, Hatzakis A. Clinicopathological features and natural history of acute sporadic non-(A-E) hepatitis. J Gastroenterol Hepatol 2008; 23: 1208-15.

10. Lai MW, Chang MH, Hsu HY. Non-A, non-B, non-C hepatitis: its significance in pediatric patients and the role of GB virus-C. J Pediatr 1997; 131: 536-40.

11. Ichai $P$, Samuel D. Epidemiology of liver failure. Clin Res Hepatol Gastroenterol 2011; 35: 610-7.

12. Cattral MS, Langnas AN, Markin RS, et al. Aplastic anemia after liver transplantation for fulminant liver failure. Hepatology 1994; 20: 813-8.

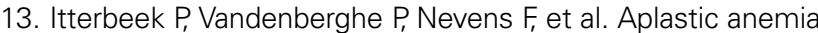
after transplantation for non-A, non-B, non-C fulminant hepatic failure: case report and review of the literature. Transpl Int 2002; 15: 117-23.

14. Tzakis AG, Arditi M, Whitington PF, et al. Aplastic anemia complicating orthotopic liver transplantation for non-A, non-B hepatitis. New Engl J Med 1988; 319: 393-6.

15. Erol I, Alehan F, Ozcay F, Canan O, Haberal M. Neurological complications of liver transplantation in pediatric patients: a single center experience. Pediatr Transplant 2007; 11: 152-9.

16. Dehghani SM, Honar N, Inaloo S, et al. Neuromuscular complication after liver transplant in children: a single-center experience. Exp Clin Transplant 2010; 8: 9-13.

17. Poff JA, Coakley FV, Qayyum A, et al. Frequency and histopathologic basis of hepatic surface nodularity in patients with fulminant hepatic failure. Radiology 2008; 249: 518-23.

18. Craig CE, Quaglia A, Selden $C$, Lowdell M, Hodgson $H$, Dhillon AP. The histopathology of regeneration in massive hepatic necrosis. Semin Liver Dis 2004; 24: 49-64. 